\title{
Corela
}

Cognition, représentation, langage

4-1 | 2006

Vol. $4, n^{\circ} 1$

\section{From sensory to propositional modality}

Towards a phenomenology of epistemic modal meanings

Jean-Rémi Lapaire

\section{(2) OpenEdition}

Journals

Édition électronique

URL : http://journals.openedition.org/corela/441

DOI : 10.4000/corela.441

ISSN : 1638-573X

Éditeur

Cercle linguistique du Centre et de l'Ouest - CerLICO

Référence électronique

Jean-Rémi Lapaire, «From sensory to propositional modality », Corela [En ligne], 4-1 | 2006, mis en ligne le 28 juin 2006, consulté le 19 avril 2019. URL : http://journals.openedition.org/corela/441 ; DOI : $10.4000 /$ corela.441

Ce document a été généré automatiquement le 19 avril 2019

\section{(c) (1) (2)}

Corela - cognition, représentation, langage est mis à disposition selon les termes de la licence Creative Commons Attribution - Pas d'Utilisation Commerciale - Partage dans les Mêmes Conditions 4.0 International. 


\section{From sensory to propositional modality}

Towards a phenomenology of epistemic modal meanings

Jean-Rémi Lapaire

We have (...) a perceptual field, a surface in contact with the world, a permanent rootedness in it (...)

The world ceaselessly assails and beleaguers subjectivity as waves wash round a wreck on the shore. All knowledge takes its place within the horizons opened up by perception. Merleau-Ponty 1962: 207

\section{Introduction}

1 It is generally assumed that epistemic modal meanings are more "abstract" than dynamic and deontic meanings. Yet, epistemic modality provides a strong case for a motion- and perception-based treatment of modality, and calls for a phenomenological conceptionofspeakers as embodied cognizers.

2 As the present article purports to demonstrate, visualandhaptic ${ }^{1}$ modalities structure much of the socio-cognitive organization of propositional modality, with EYES and HANDS operating as the metonymically salient body-parts in viewingand manipulationmodels.

As will also become apparent in the course of this presentation, reification plays a crucial role in the phenomenology of epistemic modality, since solid facts, conceivable events and consistent interpretations are typically "ceived" (Talmy 2000) as things or constructions that can be accessed or elaborated in blended mental-physical space (Lapaire 2004b). 


\section{Common assumptions and beyond}

Mainstream presentations of modality in English typically address such issues as:

33). Central members of the category include the modal auxiliaries may / might, can / could, must, will / would and shall / should. All display the "NICE properties": they occur with n egation, inversion, code, emphatic assertion.

- b. The subjectivity of modal constructions. Modality is fundamentally attitudinal ${ }^{2}:$ it $^{2}$ involves making judgements about propositions ${ }^{3}$. Modals are formal markers of subjectivity: Modality in language, especially when marked grammatically, seems to be essentially subjective. (...) Modality in language is (...) concerned with subjective characteristics of an utterance, and it could be even further argued that subjectivity is an essential criterion for modality. Modality could be defined as the grammaticalization of speakers' (subjective) attitudes and opinions." (Palmer, 1986: 16

- c. The types of modal judgements. "Certainty", "possibility", "probability" and "necessity" are understood to be "core concepts in modality" (Huddleston and Pullum 2002: 173). Thus, in "People who are prone to anxiety and pessimism may have drawn a short stick, genetically speaking” (International Herald Tribune), may codes "epistemic possibility".

Little can be objected to this, except that some sensitive cognitive issues are carefully avoided. For instance, nothing is said of the dual nature of propositions - material and notional - in our cognitive systems. As the Latin origin of the term suggests, propositions ${ }^{4}$ are objects of conceptions that can be "formed", "set forth" and "examined" with imaginary HANDS and EYES. "Attitudes" to propositions - or "modal stances" - are construed as "position" or "posture" involving some imaginary BODY standing on some imaginary FEET.

If this is correct, then it may be safely claimed that the core modal concepts of "certainty", "necessity, "consistency", etc. are related to bodily organization and sensorymotor activity. Modality makes use of the conceptual resources afforded by the imaginary body and organs of grammar. ${ }^{6}$ It has EYES that can see clearly, HANDS that can hold or press firmly, FEET on which to rest or stand.

\section{Reification}

Propositions are not just propositions - "topics presented for consideration" or "statements that affirm or deny something". Propositions are mental-material constructs that stand for a variety of things: matters to be done or dealt with; stuff that may be true or false, etc.

So many things occur that are not "things" in a strict sense - and never will be. (...) Reification - from latin res 'thing' - is the backbone of cognition. An indispensable mental tool, it involves mapping the central properties of material objects substance, shape, mass or weight - onto selected "objects" of human experience: emotions - or things felt; statements - or things said; events - or things done. (Lapaire 2004a, 452-53)

7 The reification of propositions makes it possible for "certainty " to be construed as solidity (as in the phrase solid / hard facts); for"true happenings" to be conceived as things that have materialized; for "realis assertion" to be the expression of firmstatements, etc. As will 
be shown in section 2., reification is particularly relevant to epistemic modality, since it has allowed manual-haptic scriptsfor "inference" or "extrapolation" to develop alongside viewing and journey scripts. The latter combine reification with spatializationthrough the "location metaphorical system" (Johnson 1997: 39):

ACTIONS ARE MOTIONS ALONG PATHS from one location (= state) to another statelocation. (...) STATES ARE LOCATIONS along such metaphorical action-paths, and they are understood metaphorically as bounded regions ("He's in love", "While we are in flight, please remain seated," "Stay out of trouble"). CHANGES ARE MOVEMENTS from one state-location to another. We speak of being in or out of a state, of going into or out of it, of entering or leaving it. PURPOSES ARE DESTINATIONS toward which we move. (Johnson 1997: 37)

8 The use of journey storiesto conceptualize events, together with object-creation, objectmanipulation and object-transfer stories, suggests that narrative models for human activityexistin human cognitive systemsthatare related to bodily functioning. Most prominent are:

- a. Journey and road map models, in which "doers" are construed as "travellers" and "achieving" as "getting there." The profiled body-parts are FEET and LEGS. When applied to the epistemic domain, the story shows cognizers embarking on various "mental journeys" which "lead" them to conclusions or allow them to "reach" verdicts.

- b. Object-manipulation and object-creation models, in which "doers" are construed as "creators" and their "acts" as "artefacts" (Lapaire 2004a). . The profiled body-parts are ARMS and HANDS. When applied to the epistemic domain, the story shows cognizers "making" their own judgements and "constructing" their own "structures of interpretation."

- c. Viewing models, in which ideas and events are "scenes" that cognizers "observe," "focus upon" or form mental pictures of (Lapaire 2004b). EYES are here profiled.

The models listed above make it possible for a rich phenomenology of epistemic modal meanings to develop in language and cognition, as we would like to show.

\section{Cognizing epistemic modality}

10 There is wide agreement among linguists that epistemic modality is essentially about the speaker'sknowledgeand interpretation of reality:

(Epistemic) is derived from the Greek word meaning "understanding" or "knowledge" (rather than "belief"), and so is to be interpreted as showing the status of the speaker's understanding or knowledge. This clearly includes both his own judgements and the kind of warrant he has for what he says. (Palmer 1986: 51)

11 Although the word "cognitive" does not normally occur in standard definitions of epistemic modality, epistemic modal judgments are understood to be mental- rather than pragmatic - events. "Knowledge and belief" - and more specifically "necessity, probability, or possibility in reasoning" - are expressed by the speaker who "is committed to the truth of the proposition." Such open "commitment"is usually regarded as a marked case of subjective involvement.

12 Mainstream accounts of epistemic modality are based on the "universal" categories of modal logic and a narrow repertoire of modal concepts that includes "certainty", "necessity", "possibility" and "truth" as its core items. Occasional variation in wording and emphasis may however be observed. Some presentations will underscore the importance of "subjectivity" in relation to "degrees of epistemic certainty," while others 
will devote special attention to the types of "epistemic modal judgements" involved. But the foundational character of propositional logic is rarely questioned and superficial discrepancies should not conceal deep unity of content.

Cognitive grammarians depart more radically from received views about epistemic modality. Building on Sweetser's hypothesis that deep "semantic linkage" unites root an epistemic meanings, they place special emphasis on the "extension" of conceptual mechanisms from "the sociophysical domain to the epistemic domain" (1990: 51). "Root meanings," they argue, act as cognitive primaries analysable in terms of "socio-physical forces, barriers and paths of different kinds." Once entrenched, the force-dynamic logic of root modality naturally "extends" to the "epistemic domain" (56). Such "extension" is made possible by the fact that "the epistemic world is understood in terms of the sociophysical world" (59).

My proposal is that root-modal meanings are extended to the epistemic domain precisely because we generally use the language of the external world to apply to the internal world, which is metaphorically structured as parallel to that external world. Thus we view our reasoning processes as being subject to compulsions, obligations and other modalities, just as our real-world actions are subject to modalities of the same sort. (...) Modal verbs do not have two separate unrelated senses, but rather show an extension of the basic root-sense to the epistemic domain - an extension which is strongly motivated by the surrounding linguistic system. (Sweetser 1990: 50)

The "parallel" drawn by Sweetser between "real-world actions" and "reasoning processes" should be regarded as a major breakthrough in the treatment of epistemic modal semantics, since it allows "body action stories" (Turner 1996) to be mapped onto mental events and authorizes the ceptuallinkage of epistemic modality with the sensory modalities.

15 Langacker's "basic epistemic model" (1991: 242-43) has also been a major of inspiration to cognitive grammarians. The model casts the speaker in the role of "conceptualizer (C)" accepting certain "situations" or "states of affairs" as "real." The conceptualizer's judgment pertains not so much to "absolute truth" as to what he or she "knows" or "think they know" (242). The quality and reliability of the knowledge depend on the kind of "reality" that is dealt with and the modes of "access" used. Thus, the speaker-cognizer may enjoy "perceptual access" to "portions of the immediate reality" or have "mental access" to "known reality." "Reality" itself is defined as a perceptual and / or conceptual "region," where "situations" can be "placed" or "established" with varying degrees of confidence. "Immediate known reality" surrounds the speaker (246), while the larger conceptual region of "unknown reality" contains "situations of at least two sorts: those whose reality $\mathrm{C}$ suspects or contemplates but does not accept as having been established; and those of which he is entirely ignorant"(243).

In Langacker's epistemic model, degrees of certainty have spatial analogues expressed in terms of "distance":

(The) modals can be described as contrasting with one another because they situate the process at varying distances from the speaker's position at immediate known reality. Must, for example, places it very close to known reality - the speaker had deduced that accepting it as real seems warranted (though he has not yet taken that final step) - whereas may implies that only that he regards the situation as compatible with what he knows. (Langacker 1991: 246) 
17 Although Sweetser's root-to-epistemic principle of “extension" and Langacker's "basic epistemic model" have been refined over the years, they remain a major source of inspiration to cognitive grammarians. Even those linguists that reject cognitive models must acknowledge this simple fact: epistemic modal judgements are grammatically explicit cognitive eventsthat most clearly cast speakers in the role of cognizers. The study of epistemic modality cannot be conducted without due reference to the cognizing subject, since the "beliefs" and "intellectual judgements" arrived at through "observation", "speculation" or "reasoning" necessarily involve some form of cognitive processing on the part of the speaker. Epistemic modality is proof that language truly opens a "window on thought" (Jackendoff 1993: 184). Onlookers that care to stare are likely to discern the following cognitive mechanisms and configurations:

\subsection{Epistemic modality is interpretive and conclusive}

18 The way we look at epistemic modality and refer to it as a semantic category is crucially linked to the way we cognize events and to our folk conceptions of truth and knowledge.

19 Propositions subject to epistemic modal judgments do not represent static objects of conceptions but structures of interpretation subject to dynamic mental processing. The processing is all the more active, as the coded conception is not presented as fact ${ }^{10}$ but as a form of speculation, ${ }^{11}$ i.e. a deduction, an inference ${ }^{12}$ or "appearance, based on the evidence of (possibly fallible) senses" (Palmer 1986: 51).

As Lakoff (1993) has convincingly argued, reasoning is generally construed as a mental journey, with some initial observation or premise established as a starting point and some conclusion or verdict as a finishing point. The journey model - which metonymically profiles FEET / LEGS and walking - thus seems relevant to epistemic modality, and has indeed received considerable attention from cognitive grammarians, although few have taken the trouble to relate it explicitly to bodily organization and narrative imagining. For language unfolds the story of embodied cognizers traveling along the paths of knowledge, i.e. following a particular course of reasoning and eventually reaching, coming to or arriving at a conclusion. As Huddleston and Pullum suggest in their analysis of "He must have been delayed," forces and directionality often play a key role in the mental journey to epistemic certainty, since speakers are often "led" or "forced" to inescapable conclusions (2002: 178).

21 Other body action stories exist that are equally meaningful. Stories of EYES seeing and ARMS / HANDS drawing, pulling, giving, holding, which are frequently involved the narrative construal of inference. For example, manual-haptic models structure such basic "epistemic scenes" as evidence being gathered or collected; opinions formed; hypotheses put forward; interpretations given; positive or negative judgements made and conclusions $^{13}$ drawn (from a body of evidence), etc.

Assuming that the journey, viewing and manipulation stories are not just "dead metaphors" but live structures of understanding acting as "hidden hands" in the "cognitive unconscious"14 of logicians and grammarians, then language must be the central blending medium, the great architect, the indefatigable perpetuator of the lexical integration of sensory-motor with epistemic activity. Such powerful integration is achieved by producing a single ceptual narrative in which the perceptual ${ }^{15}$ "stories" of 
walking (to a place), observing or physically manipulating (something) and the conceptual story of "deciding by reasoning" are all projected into a single blended space:

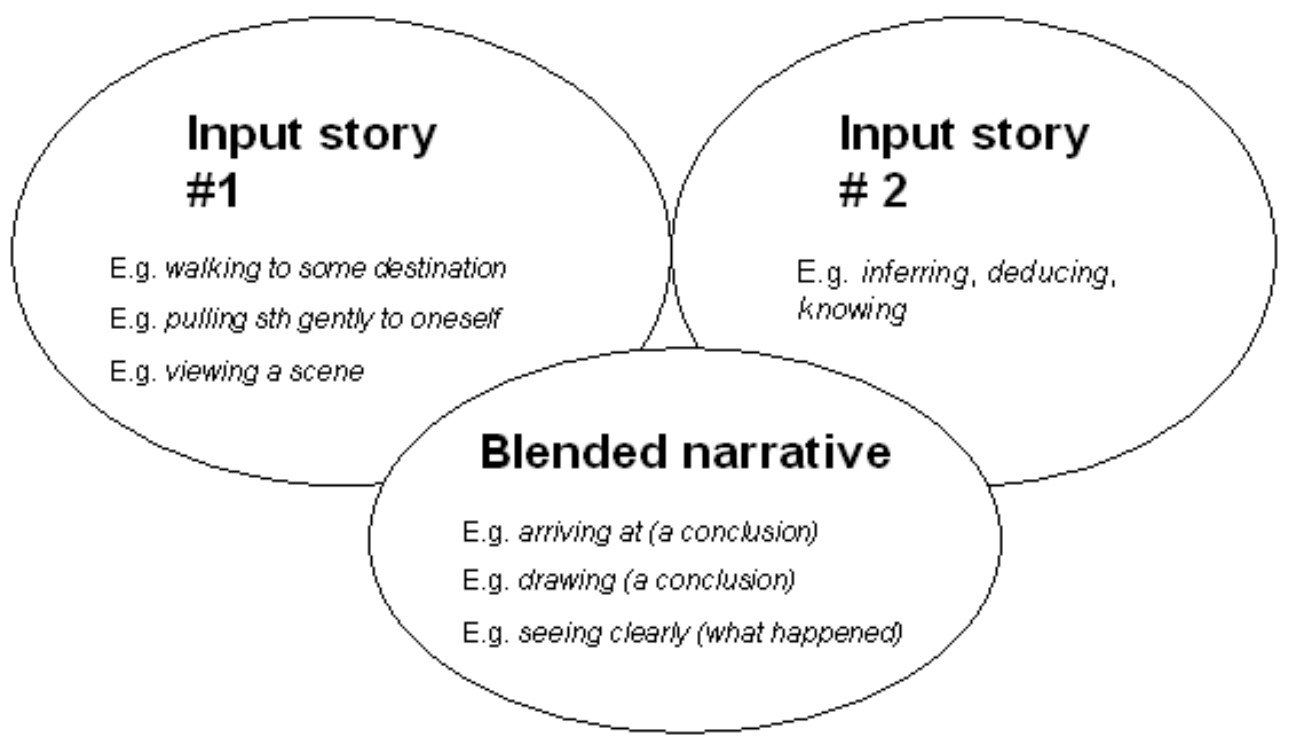

Figure 1: Blending sensory and epistemic modalities

The conceptual resources afforded by the blend are immense and unconsciously tapped by all linguists, irrespective of theoretical affiliation. Huddleston and Pullum, whose authoritative Cambridge Grammar of the English Language is anything but "cognitive", are no exception to the rule:

'Epistemic' is derived from the Greek for 'knowledge': this kind of modality involves qualifications concerning the speaker's knowledge. The unmodalised He has been delayed presents the truth of the proposition as something I know, whereas He must have been delayed presents it as something I arrive at by inference and in He may have been delayed I merely put it forward as a possibility. (Huddleston and Pullum 2002: 178. Underline is ours)

\subsection{Epistemic modality deals with the reality or truth status of propositions $^{16}$}

What is held to be "true" or "real" must acquire the "factive and veridical" status of entities presenting themselves at "a concrete level of palpability" (Talmy 2000: 144). Reality forms a ceptual region where events are construed as blended mental-material entities that can be physically and mentally located and accessed.

Regardless of the actual reliability of sensory-motor knowledge, our "sense of certainty about existence" is based on the perceptual logic of "online sensory stimulation" (Talmy 2000). Depending on the cultural role played by online perception in the establishment of knowledge, epistemic judgements of certainty will present different ceptual formats in different languages. In Western culture, were the visual and haptic channels are culturally acknowledged as trustworthy, the linguistic expression of what is or isn't "true" has a marked ceptual character, i.e. clearly integrates per-ceptual with con-ceptual experience. Despite the time old philosophical distinction between "reality" and "appearance", our culture links reality with visibility (Debré 1992) and palpability (Talmy 2000): 
Nous sommes la première civilisation (...) à avoir posé un trait d'égalité entre visibilité, réalité et vérité ${ }^{17}$. (Debré 1992: 499)

At the concrete level of palpability, an entity that one looks at is experienced as fully manifest and palpable, as clear and vivid, with the ostensive characteristics of precise form, texture, coloration (...) The entity is experienced as having real, physical, autonomous existence. (Talmy 2000: 141)

\subsection{Epistemic modality is "strong" or "weak" assertion of belief}

In many languages it is possible to make at least two kinds of epistemic judgement, a 'weak' one and a 'strong' one. A typical example is English with its modal verbs may and must. (Palmer 1986: 57)

It is widely assumed that the expression of epistemic certainty is both a rational and subjective process in which a speaker "weakly" or "strongly" asserts his or her "belief." Thus, in realis assertion (Givón 1993: 170), "the proposition is strongly asserted as true" since "the speaker has evidence or other grounds to defend his / her strong belief," while in irrealis assertion "the event is weakly asserted as either possible or likely (or necessary or desired)."

Asserting with "confidence" or "doubt" is force-dynamically expressed as making a "strong" or "weak" assertion. The "strength" of the speaker's commitment to the truth of the proposition depends on his or her discourse strategy, knowledge status ${ }^{18}$ and intellectual method ${ }^{19}$.

The first dimension [of modality] concerns the strength of commitment (prototypically the speaker's commitment) to the factuality or actualisation of the situation. This is where we distinguish the core modal concepts of necessity and possibility: necessity involves a strong commitment, possibility a weak one. (Huddleston and Pullum 2002: 175. Italics ours)

Asserting the reality of a proposition has a marked physical dimension reflected:

- a. In the body behavior of speakers as they make their epistemic judgments.

- b. In the "physical" language used to describe epistemic stances: to make a firmstatement; to express hard convictions, to gathersolid evidence on which to rest ${ }^{20}$ or base $e^{21}$ one's claims, etc.

Socio-pragmatic scripts for assertion are about pressing one's ideas, notions or conceptions onto other people, and so have a manual-haptic basis. At a more general level of cognitive organization, manual force is applied to some reified object of belief, so as to fix it firmly into the "ground" of reality" - reality being construed as a blended mentalmaterialregion where real or conceivable things can be placed with lesser or greater confidence (Lapaire 2004c). Thus, "strong epistemic judgments" of the kind exemplified by Palmer - "He must be there." "He can't be there" - establish conceptions with a firmer hand than the weaker, shakier "epistemic judgments" conveyed by may in "He may be there" (1986: 57).

30 All things considered, "the assertion of belief" or "the commitment to the truth of a proposition" cannot be considered as purely rational acts, removed from spatial and sensory-motor experience. The verticality schema that structures the so-called epistemic scale of certainty is rooted in spatial experience. The modal may in He may be right expresses a "low" degree of certainty, compared to must in He must be right, which codes a "high" degree. Epistemic gradients are found everywhere in the literature and unquestionably reflect a spatial construal of intensity ${ }^{22}$ applied to "modal judgements." Finally, socio-physical pressure and forces are manifest in the core notion of strength of 
assertion, since propositions are said to be weakly or strongly asserted, depending on the extent of the speaker's "commitment."

\subsection{Epistemic certainty as intellectual vision: the epistemic viewing model}

Numerous aspects of construal that are quite important linguistically can reasonably be interpreted as general conceptual analogues of phenomena well known in visual perception. (Langacker 2000: 206)

There exists a visual grammar of epistemic modality, which is but one instantiation of the more general ceptual metaphor UNDERSTANDING IS SEEING, originally studied by Lakoff and Johnson (1980: 48). In the epistemic viewing model, objects of conceptions have visible outline or shape, and cognizers are viewers. The visual analogs of certainty are clarity and sharpness:

The parameter of clarity is a gradient at the high end of which an entity is experienced as being clear, distinct, and definite. At the low end, an entity is experienced as being vague, indistinct, indefinite, or murky. (Talmy 2000: 141)

Having certain knowledge of a particular situation is analogous to getting a clear or sharp picture of the scene. The sense of clarity and specificity is enhanced if the picture is "finegrained" or has a "high definition." Conversely, a lower degree of epistemic certainty has a "blurring effect" (Givón 1993: 183), preventing sharp intellectual vision. Different modals produce different viewing arrangements or code different visual experiences. The sharpness of will and must can thus be contrasted with the "haziness", "fogginess" or "blurredness" of may:

(1) Italy's economy will / may grow less next year than the government is forecasting, two separate reports said.

(2) You are / may be wrong; she is / may be passionately devoted to her child.

(3) That must / will / may be her waiting at the door.

(4) You'll love it / may not like it.

In the epistemic viewing model, the "epistemic certainty gradient" (Givon 2001: 314)) has the following visual analogs:

- Subjective Certainty As Sharp Mental Image

- Absolute Certainty As Clarity and / or Transparency

- Low Certainty As Poor Visibility / Fuzzy Picture

- High Certainty As Clear View / Sharp Picture

More would deserve to be said about "mental vision" in relation to prediction and extrapolation (see Lapaire 2004b). Suffice it to say that the visual format imposed on epistemic modal semantics is proof enough of the existence of a true phenomenology of modality.

\subsection{Epistemic meaning making: the epistemic workshop model}

In the epistemic workshop, the deductive or interpretive work performed by speakers is construed as a creative enterprise. Cognizers act as creators or builders that make judgements, produce interpretations, form opinions, etc. using facts and pieces of evidence as construction material and rational capacities as technical skill. 
Epistemic judgments are thus cognized as products or constructs that are elaborated and manipulated as speakers express their beliefs. Propositions are firmly or tentatively "placed" (Latin ponere) before the addressee, while conjectures or "thrown" (Latin jacere) into the realm of possibility. In either case, the object or construct must resist the antagonistic, unsettling, or disintegrating forces of contradiction (Lapaire 2004c). Consistent ${ }^{23}$ interpretations must "stand" to reason or "withstand" attack(Latin stare "to stand"). Weak arguments are shaky and likely to collapse. Untenable theories of truth (Latin tenere "to hold")cannot be "upheld" or maintained ${ }^{24}$ for long, and may ultimately have to be withdrawn lest they crumble, collapse or fall apart.

In the epistemic workshop, the mind has imaginary HANDS that produce objectsof conceptions and structuresof interpretation:

- Mental Activity As Manual Work

- Reasoning Skill As Manual Skill

- Meaning As Substance

- Interpreting As Forming, Shaping, Assembling or Building

- Asserting As Fixing, Placing

- Assurance As Firmness

- Accepting As Taking, Holding

- Agreeing As Touching

- Reality As Mental-Material Region Filled with Things

- Real As Standing There

- Certainty As Tangibility

- Consistency As Solidity and / or Balance

- etc.

It is important to note that manual-haptic conceptions of "mental work" listed above, require the activation of image schemata (Johnson 1987) such as the THING-schema; the FORCE-Schema, the BALANCE-Schema, the CONTAINER-schema and the PART-WHOLE schema.

\subsection{Performing epistemic modality}

The visual and manual-haptic models that structure epistemic certainty are rooted in early sensory-motor intelligence and therefore entrenched in everyday cognition. If they were not, then short gesture performances "illustrating" epistemic modal meanings would be of little heuristic value. Quite the opposite seems to be true. For example, metaphoric hand gestures showing how the past may be "reconstructed" with the preterit and modal constructions are most efficient with learners. The simple past establishes "solid facts"(She knew him); while must have is used to set up a structurethat "stands firmly in the ground" (She must have known him). Can't have "brushes aside" inconsistencies (She can't have met him) and may've codes a form of oscillation or "swaying" (She may have met him).

A "performance" of epistemic modality where propositions are theatrically "held" to be true or "dropped" as unacceptable, where sharp and blurred pictures of events are displayed and scrutinized, make a lot of sense to learners, thereby confirming the cognitive reality of the ceptual link between sensory and propositional modalities (Lapaire \& Masse 2005). 


\section{Concluding remarks}

40 Cognitive linguistics and functional grammar have paved the way for promising new sensory-motor approaches to modality. Talmy's influential paper on "Force dynamics in Language and Cognition" (1985), Sweetser's convincing argument that the forces, paths and barriers of "socio-physical modality" extend to "the world of reasoning" (1990), Givón's notion of "manipulation" as a semantic and syntactic verb-category (1993), all suggest that viable "phenomenological" alternatives to traditional modal logic exist that are worth developing.

41 Even the most "rational" types of logical reasoning associated with epistemic modality inferential, deductive, conclusive - are related to sensory-motor experience and imaginatively structured by a number of scripts and schemata that achieve the narrative compression and simplification of complex ceptual mechanisms.

Assuming that symbolic structure is a faithful revealer of conceptualizing mechanisms, then lexical idioms like "it stands to reason", "it makes (good) sense", "it is quite consistent", "it holds" indicate thatepistemic viewing and meaning making are part of the conceptual organization of the grammar of modality.

The central claim made in this article that epistemic modal systems are not removed from the perceptual and motor systems of speakers and, more generally, that perception and motion are an integral part of reason should not be considered a challenge to logical and truth-conditional systems. If anything, the theory of embodied rationality (Lakoff \& Johnson 1980) can serve as a useful, thought-provoking additive to the time-proven modal logic inherited from Aristotle and scholasticism. It may play an even greater role if one makes the assumption that Merleau-Ponty's "subject of perception" (1962: 207) is not only relevant but central to the grammar of modality, as the rich evidential systems ${ }^{25}$ found in many languages attest ${ }^{26}$. Such systems overtly connect sensory evidence - in particular "hearing" and "seeing" - with epistemic certainty. The connection, although less apparent in English, might be worth investigating there too. Results, it is hoped, should speak in favor of an integrative, multi-dimensional grammar of modality incorporating, among other relevant parameters, visual and manual-haptic concepts. Thus, remarks on visual and tactile analogues of epistemic certainty, sweeping statements about the centrality of substance, contact and manipulation in grammar, might some day be treated as more than amusing "phenomenological postscripts" refreshingly added to the sterner logical descriptions that dominate the field of modality in English. Indeed, vision, touch and manipulation might move from the fringes to the centre and some day become "the heart of the matter."

\section{BIBLIOGRAPHIE}

Adamczewski, Henri \& Claude Delmas. 1982. Grammaire linguistique de l'anglais. Paris: Armand Colin. 
Bottineau, Dider. 1998. Aspect, actance et modalité: systématique de l'infinitif anglais. PhD dissertation, University of Paris IV-Sorbonne.

Bottineau, Didier. 2004a. «Towards a cognitive modelization of the English modals», paper given at the 2d International Conference on Modality in English (ModE 2), U-Pau, 2-4 sept. 2004.

Bottineau, Didier. 2004b. «Le cognème $<M>$, marque linguistique de la présence de l'auteur dans les grammèmes anglais», in D. Banks (ed.), Les marqueurs linguistiques de la présence de l'auteur. Paris: L'Harmattan, 143-164.

Bouscaren, Janine, Alain Deschamps \& Lionel Dufaye (eds.). 2001. Modalités et opérations énonciatives. Cahiers de recherche en grammaire anglaise. Gap/Paris: Ophrys.

Bybee, Joan, Revere Perkins \& William Pagliuca. 1994. The Evolution of Grammar. Tense, Aspect and Modality in the Languages of the World. Chicago/London: The University of Chicago Press.

Cotte, Pierre. 1997. Grammaire linguistique. Collection CNED - Didier Concours. Paris: Didier Erudition.

Cotte, Pierre. 2000. « La modalité de commentaire, la modalité comme commentaire », in La Modalité et les modaux en diachronie et en synchronie (domaine anglais), J. Pauchard (ed.), Recherches en Linguistique et Psychologie cognitive 14, 201-224. Reims : Presses Universitaires de Reims.

Croft, William. 1991. Syntactic Categories and Grammatical Relations. The Cognitive Organization of Information. Chicago/London: The University of Chicago Press.

Culioli, Antoine (ed.). 1986. Aspects, modalité: problèmes de catégorisation grammaticale. Département de recherches linguistiques. Laboratoire de linguistique formelle. Paris: Université de Paris 7.

Culioli, Antoine. 1990. Pour une linguistique de l'énonciation. Opérations et représentations. Tome 1. Gap / Paris: Ophrys.

Debray, Régis. 1992. Vie et mort de l'image. Paris: Gallimard.

Douay, Catherine. 2000. Eléments pour une théorie de l'interlocution: un autre regard sur la grammaire anglaise. Rennes: Presses Universitaires de Rennes.

Dufaye, Lionel. 2001. Les modaux et la négation en anglais contemporain. Gap / Paris: Ophrys.

Dufaye, Lionel. 2006. Les auxiliaires de modalité: pouvoir, devoir, can, may, must, should, comment s'y retrouver? Gap / Paris: Ophrys.

Gilbert, Eric. 1987. May, must, can et les opérations énonciatives. Gap: Ophrys.

Gilbert, Eric. 2001. "Vers une analyse unitaire des modalités." In Modalité et opérations énonciatives, Cahiers de recherches en grammaire anglaise, Tome 8. Janine Bouscaren, Alain Deschamps, Lionel Dufaye (eds.). Gap/Paris: Ophrys.

Givón, Talmy. 1993. English Grammar. A Function-Based Introduction. Volume 1. Amsterdam/ Philadelphia: John Benjamins Publishing Company.

Hopper, Paul \& Elizabeth Closs Traugott. 2003. Grammaticalization. Second Edition. Cambridge: Cambridge University Press.

Joly, André \& Dairine O’Kelly. 1990. Grammaire systématique de l'anglais. Paris: Nathan.

Johnson, Mark. 1987. The Body in the Mind. The Bodily Basis of Meaning, Imagination, and Reason. Chicago: The University of Chicago Press.

Lakoff, George. 1993. "The contemporary theory of metaphor." In Metaphor and Thought, edited by Anrew Ortony, 202-51. Cambridge: Cambridge University Press. 
Lakoff, George and Mark Johnson. 1980. Metaphors We Live By. Chicago: The University of Chicago Press.

Lakoff, George and Mark Johnson. 1999. Philosophy in the Flesh. New York: Basic Books.

Langacker, Ronald. 1991. Foundations of Cognitive Grammar. Stanford: Standford University Press.

Lapaire, Jean-Rémi. 2002. “Imaginative grammar." In Cognitive Linguistics Today, 623-42. Barbara Lewandowska-Tomaszczyk \& Kamila Turewicz (eds.). Frankfurt / M: Peter Lang.

Lapaire, Jean-Rémi. 2004a. "Act, fact and artefact. The workshop model for action and causation." In Linguagem, Cultura e Cognição: Estudos de Linguística Cognitiva, 451-72. Augusto Soares da Silva, Amadeu Torres, Miguel Gonçalves (eds.). Coimbra: Almedina.

Lapaire, Jean-Rémi. 2004b. "Imagistic dimensions of futurity. How French and English picture the future.” In Imagery in Language. Barbara Lewandowska-Tomaszyck (Ed.) Lódź Studies in Language. Volume 10. Frankfurt/M: Peter Lang, 2005.

Lapaire, Jean-Rémi. 2004c. "Negation, reification and manipulation in a cognitive grammar of substance." Paper presented at the International Conference on Negation held at the University of Tours, France.

Lapaire, Jean-Rémi. 2005. La grammaire anglaise en mouvement. Paris: Hachette.

Lapaire, Jean-Rémi \& Jean Masse. 2005. Grammar in Motion. English grammar explained on DVD using short, metaphoric gesture performances (KineGrams). In Lapaire, Jean-Rémi La grammaire anglaise en mouvement, 2005.

Larreya, Paul. 1984. Le possible et le nécessaire. Paris: Nathan.

Larreya, Paul. 2000. «Connaissance, inférence et modalités épistémiques dans le système verbal de l'anglais ». In J. Pauchard (ed.) La modalité et les modalités et les modaux en diachronie et en synchronie (domaine anglais), Recherches en Linguistique et Psychologie cognitive 14, 175-199. Reims: Presses Universitaires de Reims.

Meier, Richard P., Kearsy Cormier and David Quinto-Pozos (Eds). 2002. Modality and structure in signed and spoken languages. Cambridge: CUP.

Merleau-Ponty, M. 1962. Phenomenology of Perception. Translated from the French ( $L a$ phénomenologie de la perception) by Colin Smith. London/New York: Routledge.

McNeill, David. 1992. Hand and Mind. What Gestures Reveal about Thought. Chicago/London: The University of Chicago Press.

McNeill, David. 2005. Gesture and Thought. Chicago/London: The University of Chicago Press.

Özçalişan, Seyda. 2005. "On learning to draw the distinction between physical and metaphorical motion: is metaphor an early emerging cognitive and linguistic capacity?" Journal of Child Language 32, 291-318. Cambridge: Cambridge Unversity Press.

Palmer, F.R. 1986. Mood and Modality. Cambridge: Cambridge University Press.

Palmer, F.R. 1987. The English Verb. London: Longman.

Palmer, F.R. 1994. Grammatical roles and relations. Cambridge: Cambridge University Press

Pottier, Bernard. 2000. Représentations mentales et catégorisations linguistiques. Louvain / Paris: Peeters. 
Robert, Stéphane. 1986. «Etat résultant, aspect et modalité dans le paradigme dit "énonciatif" en wolof.» In Aspect, modalité, Département de linguistique, Coll. ERA 642., 121-153. Paris: Université de Paris 7.

Robert, Stéphane. 1994. «Sur le rôle du sujet parlant dans la construction du sens: liens entre temps, aspect et modalité.» In M. Yaguello, Subjecthood and Subjectivity, 209-229. Paris / Gap: Ophrys.

Salkie, Raphael. 2004. "Towards a non-unitary analysis of modality." In Contrastes: mélanges offerts à Jacqueline Guillemin-Flescher. Lucie Gournay, Jean-Marie Merle (eds.). Gap/Paris: Ophrys.

Sweetser, Eve. 1990. From Etymology to Pragmatics. Metaphorical and Cultural Aspects of Semantic Structure. Cambridge: Cambridge University Press.

Talmy, Leonard. 2000. Toward a Cognitive Semantics. Volume 1. "Fictive motion in language and ception" (99-175). Cambridge, Mass / London, England: The M.I.T. Press.

Trask, R.L. 1993. A Dictionary of Grammatical Terms In Linguistics. London/New York: Routledge.

Turner, Mark. 1996. The Literary Mind. The Origins of Thought and Language. New York/ Oxford: Oxford University Press.

\section{NOTES}

1. Related to or based on the sense of touch.

2. In Huddleston and Pullum's words, "modality is in the first instance a matter of the speaker's attitude" (2002: 173).

3. (...) the modality codes the speaker's attitude toward the proposition. By 'attitude' we mean here primarily two types of judgement made by the speaker concerning the propositional information carried in the clause:

Epistemic judgements of truth, probability, certainty, belief or evidence.

Evaluative judgements of desirability, preference, intent, ability, obligation or manipulation. (Givón 1993: 169)

4. From Latin pro- "forward, out" + ponere "to place".

5. From Latin stare "to stand".

6. "Le corps et les organes imaginaires de la grammaire" (Lapaire 2005: 37)

7. "The area of mood concerned with knowledge and belief, including at least the expression of possibility, probability and certainty (as perceived by the speaker), and, in some views, also the expression of the speaker's degree of commitment to what she/he says, as, for example, by the use of evidentials." (R.L. Trask 1993: 92)

8. "Linguists have characterized as root those meanings which denote real-world obligation, permission, or ability (as in example [1]); and as epistemic those which denote necessity, probability, or possibility in reasoning (as in [2]).

(1) John must be home by ten; Mother won't let him stay out any later.

(2) John must be home already; I see his coat." (E. Sweetser 1990: 49)

9. "Epistemic modality applies to assertions and indicates the extent to which the speaker is committed to the truth of the proposition. The unmarked case in this domain is the total commitment to the truth of the proposition, and markers of epistemic modality indicate something less than a total commitment by the speaker to the truth of the proposition." (Bybee et al. 1994: 179) 
10. Fact, from Latin factum "something done", from factus "made," from facere "to make." An event or thing known to have happened or existed, a truth verifiable from experience or observation, (legal) an actual event, happening, etc. (Collins English Dictionary).

11. From Latin speculari "to spy out" from specere "to look at."

12. From Latin inferre "to bring into," from ferre "to bear, to carry."

13. From Lat. concludere "to enclose" from claudere "to close."

14. Hidden hands and cognitive unconscious refer to Lakoff and Johnson (1999).

15. Perceptual is here used in Talmy's extended sense, covering all kinds of sensory-motor experience, not just sensation.

16. "An epistemic modal is used to express a judgment by the speaker about the truth of the proposition he is presenting." (Palmer 1987: 98)

17. "Visible $=$ Real $=$ True". "We are the first civilization (...) ever to have equated visibility with reality and truth."

18. For a discussion of "knowledge status" see Talmy 2000: 155-56.

19. E.g. logical inference (She was born after the war, so she can't have known him) vs. personal extrapolation from present circumstances (She must be desperate to leave).

20. From Latin re- + stare "to stand."

21. The abstract use of basis is essentially ceptual since it blends the material configuration of some concrete surface or object underlying or supporting something, with the intellectual configuration of some "foundational" principle on which some idea "rests". From Greek bainein "to step, to go."

22. From Latin intendere "to stretch out."

23. From Latin consistere "to stand firm," from sistere "to stand, to cause to stand", Latin stare "to stand"

24. From French maintenir, literally"to hold in the hand," from Latin manu tenere.

25. "A grammatical category occurring in some languages by which all statements (and sometimes other sentence types) are overtly and obligatorily marked to indicate the source of the speaker's evidence for her/his utterance. (...) Evidential systems, which are sometimes called verification systems, are sometimes regarded as forming part of mood systems in languages exhibiting them." (Trask 1993: 95)

26. Languages that have marked systems of inferential modality connect sensory evidence with (epistemic) certainty. As Palmer remarks in his discussion of evidentials (1986: 67-76), direct observation (witnessing, recording) is sometimes presented as fallible.

\section{RÉSUMÉS}

L'univers mental de la modalité épistémique n'est pas entièrement coupé de l'univers physique des objets et des substances que les êtres humains perçoivent et avec lesquels ils interagissent. Il existe un lien métaphorique entre attitudes (ou postures) modales et attitudes (ou postures) corporelles, comme l'atteste l'emploi courant d'expressions visuelles et manuelles pour exprimer les notions ou processus modaux. L'énonciateur-conceptualisateur exécute symboliquement une gestualité mentale et s'implique dans des scènes «ceptuelles" de vision, de mouvement et de manipulations épistémiques. Les hypothèses sont «forgées", les faits sont "posés", les jugements "appliqués» ou "assénés» avec plus ou moins de «force». Les conclusions sont 
«atteintes» et les déductions «faites» ou «opérées». Les structures interprétatives sont «construites». Les arguments logiques «tiennent debout». L'incohérent «s'écroule» ou «s'effondre ». Les analogies perceptuelles les plus courantes de la certitude et de l'évidence sont la «clarté », la «transparence " ainsi que la «solidité. Les propositions sont des objets de conceptions hybrides, intégrant le matériel au mental, localisés dans des espaces matériels et mentaux mixtes. Le corps symbolique de la cognition y accède, en utilisant les organes, perceptions et mouvements imaginaires inscrits dans le langage.

The mental world of epistemic modality is not entirely removed from the material world of objects and substances that humans perceive and interact with. Modal stances are symbolically related to physical stances and metaphorically described in terms of visual and manual-haptic experience. Cognizers perform mental gestures and engage in "ceptual"scenes of epistemic vision, motion and manipulation. Thus, hypotheses are "formed"; while assertions, judgements and conjectures are "made" with varying degrees of "strength". Conclusions are typically "reached" and inferences "drawn". Interpretations are "constructs". Logical arguments "stand". Inconsistent statements "collapse" or "fall apart". The common perceptual analogues of certainty are "clarity" and "solidity". Propositions are blended mental-material objects of conception that the imaginary body of cognition accesses in blended mental-physical space, using the imaginary organs, perceptions and motions encoded in the language.

\section{AUTEUR}

\section{JEAN-RÉMI LAPAIRE}

Université Michel de Montaigne-Bordeaux 3, France. 